\title{
Inhibition of proliferation and migration of luminal and claudin-low breast cancer cells by PDGFR inhibitors
}

\author{
Leanne Stalker ${ }^{1}$, James Pemberton ${ }^{1}$ and Roger A Moorehead ${ }^{1,2^{*}}$
}

\begin{abstract}
Background: Platelet-derived growth factors (PDGFs) bind to two receptors, PDGFRa and PDGFR $\beta$ to mediate cell proliferation, migration and survival. Although epithelial cells typically do not express high levels of PDGFRs, their expression has been reported to increase in breast cancer cells that have undergone epithelial to mesenchymal transition.

Methods: PDGFR signaling was inhibited using Sunitinib malate, Imatinib mesylate or Regorafenib in murine and human luminal-like and claudin-low mammary tumor cell lines or Masitinib in only the human cell lines. A scratch wound assay was used to assess tumor cell migration while immunofluorescence for phosphorylated histone $\mathrm{H} 3$ or cleaved caspase 3 was used to determine tumor cell proliferation and apoptosis, respectively.

Results: Sunitinib and Regorafenib, but not Imatinib, were capable of significantly inhibiting the migration of both murine and human luminal-like and claudin-low breast cancer cells while Masitinib inhibited migration in both human breast cancer cell lines. Sunitinib but not Regorafenib or Imatinib also significantly suppressed tumor cell proliferation in all four cell lines tested while Masitinib had no significant effect on human breast cancer cell proliferation. None of the PDGFR inhibitors consistently regulated mammary tumor cell apoptosis.

Conclusion: Sunitinib, Regorafenib and Masitinib may prove clinically useful in inhibiting breast cancer cell migration and metastasis while only Sunitinib (and possibly Regorafenib in some breast cancer subtypes) is effective at inhibiting both migration and proliferation of breast cancer cells.
\end{abstract}

\section{Introduction}

Platelet derived growth factors (PDGFs), as the name suggests, were originally purified from platelets [1-4]. PDGFs form homodimers consisting of A-, B-, C- and D-polypeptides or heterodimers consisting of $\mathrm{A}$ and $\mathrm{B}$ polypeptides. These ligands induce signaling by binding to one of two PDGFR receptor isoforms, PDGFR $\alpha$ and PDGFR $\beta$. PDGFR $\alpha$ binds all members of the PDGF dimers other than D-polypeptides while PDGFR $\beta$ bind the B- and D-polypeptides [5]. PDGFRs are tyrosine kinase receptors and ligand binding induces receptor dimerization and intracellular signaling including activation of PLC $\gamma$, Src, SHP-2, RasGAP, PI3-kinase and STAT proteins [5]. These

\footnotetext{
* Correspondence: rmoorehe@uoguelph.ca

'Department of Biomedical Sciences, Ontario Veterinary College, University of Guelph, Guelph, ON N1G2W1, Canada

${ }^{2}$ Department of Biomedical Sciences, Ontario Veterinary College, University of Guelph, 50 Stone Road East, Guelph, ON N5A7Z1, Canada
}

signaling pathways regulate cell proliferation, survival, chemotaxis and differentiation.

PDGFRs are typically not expressed in normal epithelial cells but are expressed in fibroblasts and smooth muscle cells [6] where these receptors regulate physiologic processes such as wound healing, inflammation and angiogenesis [7]. Tumors associated with enhanced PDGFR signaling include sarcomas, gastrointestinal stromal tumors and several types of leukemias [8].

With respect to breast cancer, less is known about the importance of PDGFs or PDGFRs. Studies have shown that PDGF-D is upregulated in invasive breast cancer while PDGF-BB is found at higher levels in patients with breast cancer compared to those with benign breast disease and the expression PDGFRs is a predictor of poor prognosis [9-11]. Additionally, more recent research has found that PDGF signaling is elevated in breast cancer cells that have become resistant to endocrine therapy 
$[12,13]$. Another potential role of PGDFR signaling in breast cancer is during epithelial to mesenchymal transistion (EMT). EMT is a process whereby epithelial cells acquire a more mesenchymal phenotype and gene expression profile and EMT has been implicated in more aggressive/metastatic breast cancers [14-17].

A number of agents capable of inhibiting PDGFR signaling have been developed including Sunitinib malate (Sutent), BAY 73-4506 (Regorafenib) and Imatinib mesylate (Gleevec). Sunitinib malate inhibits PDGFR $\beta$, VEGFR2, Kit and FLT-3 [18-20]. This agent is currently FDA approved for the treatment of gastrointestinal stromal tumors, pancreatic neuroendocrine tumors and renal cell carcinoma and is currently in clinical trials for the treatment of breast cancer (www.cancer.gov). Regorafenib is FDA approved for the treatment of colorectal cancer and gastrointestinal stromal tumors (www.cancer.gov). Regorafenib can bind to and inhibit PDGFR $\beta$ as well as VEGFR2, VEGFR3, Ret, Kit and Raf [21,22]. Imatinib mesylate is FDA approved for the treatment of acute lymphoblastic leukemia, chronic eosinophilic leukemia, chronic myelogenous leukemia, germatofibrosarcoma protuberans, gastrointestinal stromal tumor, myelodysplastic/ myeloproliferative disorders and systemic mastocytosis. Imatinib mesylate inhibits PDGFR $\alpha / \beta$, c-kit and bcr-abl (www.cancer.gov). A more recently described inhibitor of PDGFR $\alpha$ and PDGFR $\beta$ is Masitinib. Masitinib inhibits Kit, PDGFR $\alpha$, PDGFR $\beta$ and Lyn [23]. Masitinib is not FDA approved for any human cancers but is approved for use in canine mast cell tumors [24].

We have previously shown that PDGFRs were elevated in a murine mammary tumor cell line that has mesenchymal characteristics and closely resembles the human breast cancer subtype, claudin-low [25-27]. Claudin-low tumors are similar to basal-like breast cancer in that they are typically estrogen receptor, progesterone receptor and HER2 negative and express a number of mesenchymal genes. Claudin-low tumors are differentiated from basallike tumors by the higher expression of genes involved in immune response, cell communication, extracellular matrix, cell migration and angiogenesis and their lower expression of claudins 3, 4, 7, and occludin [28,29]. We also showed previously that knockdown of PDGFR $\alpha$, or knockdown of both PDGFRs significantly inhibited migration but did not inhibit proliferation or promote apoptosis in our claudin-low murine mammary tumor cell line [25].

In the current manuscript we extended our previous work to determine whether inhibitors of PDGFR could suppress migration and survival of murine and human luminal and claudin-low mammary tumor cells. We found that Sunitinib malate and Regorafenib significantly inhibited migration of all 4 cell lines tested. Sunitinib was also capable of suppressing proliferation in all 4 cell lines while
Regorafenib suppressed proliferation only in the human claudin-low breast cancer cell line. Imatinib only significantly inhibited migration in the human luminal breast cancer cell line and had no significant effect on proliferation in any of the cell lines. Masitinib inhibited migration of both human breast cancer cell lines but had no effect on proliferation or apoptosis.

\section{Materials and methods}

\section{Cells and culture conditions}

RJ345 and RJ348 cells were generated in our lab and have previously been described [30]. RJ345 and RJ348 cells were cultured in DMEM containing 10\% FBS, $1 \mathrm{mmol} / \mathrm{L}$ sodium pyruvate, $10 \mathrm{mmol} / \mathrm{L}$ HEPES, $4 \mathrm{mmol} / \mathrm{L}$ glutamine, $2 \mathrm{mmol} / \mathrm{L}$ hydrocortisone, $5 \mu \mathrm{g} / \mathrm{mL}$ estrogen, $5 \mu \mathrm{g} / \mathrm{mL}$ prolactin, $10 \mu \mathrm{g} / \mathrm{mL}$ epidermal growth factor, $10 \mu \mathrm{g} / \mathrm{mL}$ insulin and $1 \%$ antibiotic/antimycotic. MCF-7 cells were maintained in $\alpha$-MEM media containing $10 \%$ FBS and 1\% antibiotic/antimycotic while MDA-MB-231 were maintained in RPMI media containing 10\% FBS and $1 \%$ antibiotic/antimycotic.

\section{PDGFR inhibitors}

Regorafenib (Bay 73-4506), Imatinib mesylate (Gleevec), Masitinib (AB1010), and Sunitinib malate (Sutent) were purchased from Selleck Chemicals (Houston TX). All inhibitors were re-suspended in DMSO.

\section{Scratch wound assay}

Cells were plated in 6-well plates in fully supplemented media such that they were $90-100 \%$ confluent at the time the scratch was performed. Once the scratch was made the media was removed and replaced with fully supplemented media containing different concentrations of Masitinib, Regorafenib, Sunitinib or Imatinib. Images of the scratch were captured immediately after the scratch was induced and 24 or 48 hrs after drug administration. Percentage of the wound closed was calculated using ImageJ software $(\mathrm{NIH})$. All drugs were diluted such that each well contained $0.1 \%$ DMSO and the control well contained $0.1 \%$ DMSO.

\section{Immunofluorescence}

Cells were plated in fully supplemented media on sterile glass coverslips in 6 well dishes at $20-30 \%$ confluence. Cells were allowed to adhere overnight and then the medium was removed and replaced with fully supplemented media containing Masitinib, Regorafenib, Sunitinib, or Imatinib. All drugs were diluted such that each well contained $0.1 \%$ DMSO and the control well contained $0.1 \%$ DMSO. Twenty-four hours later the media was removed, the cells washed 3 times in ice cold PBS and then fixed in $10 \%$ neutral buffered formalin for 1 hour at room temperature. Cells were washed 3 times in PBS 
and blocked with 5\% BSA in PBS containing 0.1\% Tween 20. For proliferation, cells were incubated with a 1:2000 dilution of an antibody against phospho-histone H3 (S10) (Abcam Inc, Toronto, ON; cat\# ab14955) overnight at $4^{\circ} \mathrm{C}$. For apoptosis, cells were incubated with a 1:500 dilution of an antibody against cleaved caspase 3 (EMD Millipore, Billerica, MA; cat\# AB3623) overnight at $4^{\circ} \mathrm{C}$. The cells were then washed twice in PBS and incubated with a 1:200 dilution of the appropriate fluorescently labeled secondary antibody for 1 hour at room temperature. Cells were washed, counterstained with DAPI and visualized using an Olympus BX61 fluorescent microscope (Olympus, Center Valley, PA) using Metamorph imaging software (Molecular Devices, Sunnyvale, CA). The number of positive cells and total number of cells were counted from at least 3 independent experiments.

\section{Statistics}

An ANOVA followed by a Dunnett's posthoc analysis was performed to determine statistically significant values. Values were considered significant when $\mathrm{p}<0.05$.

\section{Results}

We have previously shown that RJ348 cells have characteristics similar to human claudin-low breast cancer while RJ345 cells resemble human luminal breast cancer [26]. We have also previously shown that RJ348 cells have elevated levels of PDGFR $\alpha$ and PDGFR $\beta$ compared to RJ345 cells and RNAi mediated knockdown of PDGFRs inhibited migration of RJ348 cells [25]. Although useful as a scientific tool, RNAi has limited therapeutic potential. Therefore, we evaluated the ability of several PDGFR inhibitors to regulate proliferation, apoptosis and migration in luminallike and claudin-low breast cancer cells.

Since the most dramatic effect observed following PDGFR knockdown in the RJ348 cells was an inhibition of tumor cell migration [25] , tumor cell migration was evaluated using a scratch wound assay and Regorafenib, Sunitinib and Imatinib were tested at $100 \mathrm{nM}, 500 \mathrm{nM}$ and $5 \mu \mathrm{M}$. All of the inhibitors were re-suspended in DMSO and all dilutions were performed in DMSO such that each well received the inhibitor and $0.1 \%$ DMSO. Control wells contained 0.1\% DMSO. Figure 1A-D shows representative scratch wounds for RJ348 cells at time 0 (when the scratch was made) and 24 hours after inducing the wound in cells treated with DMSO or Sunitinib at $5 \mathrm{uM}$. The bar graphs (Figure 1E,F) represent the percent of the wound that closed $24 \mathrm{hrs}$ after wounding for the RJ348 cells and $48 \mathrm{hrs}$ after wounding for the RJ345, MCF-7 and MDAMB-231 cells. The murine claudin-low mammary tumor cell line, RJ348, migrated more rapidly than the luminallike mammary tumor cell line, RJ345. In fact, the RJ348 cells migrated so quickly that the control cells (DMSO) completely closed the wounds by $48 \mathrm{hrs}$ and thus the
$24 \mathrm{hr}$ time point was used for these cells. The human claudin-low cell line, MDA-MB-231, migrated more quickly than the luminal breast cancer cell line MCF-7 as illustrated by comparing the DMSO controls for the two cell lines. Regorafenib, Sunitinib and Imatinib failed to significantly reduce tumor cell migration when administered at $100 \mathrm{nM}$ (data not shown). Only Sunitinib significantly reduced migration at $500 \mathrm{nM}$ and this was only observed in the RJ348 cells (Figure 1E). At $5 \mu \mathrm{M}$, both Sunitinib and Regorafenib significantly inhibited migration in all cell lines while Imatinib only inhibited MCF-7 migration (Figure 1F).

Next, cell proliferation in response to $5 \mu \mathrm{M}$ of each inhibitor was evaluated. Figure 2 shows cell proliferation relative to the DMSO control and it was observed that $5 \mu \mathrm{M}$ of Sunitinib significantly inhibited cell proliferation in all 4 cell lines while Regorafenib $(5 \mu \mathrm{M})$ significantly inhibited proliferation only in MDA-MB-231 cells. Imatinib $(5 \mu \mathrm{M})$ did not significantly inhibit proliferation in any of the cell lines.

When apoptosis was evaluated, only $5 \mu \mathrm{M}$ of Sunitinib significantly induced apoptosis and this was only observed in the RJ345 cells. The graph in Figure 3 represent the percentage of apoptotic cells in each treatment and as can be seen in the graph, the levels of apoptosis were very low. The RJ345 cells treated with $5 \mathrm{uM}$ of Sunitinib had the highest level of apoptosis and even this was only observed in approximately $1.8 \%$ of the cells.

A more recently identified inhibitor of PDGFR $\alpha$ and PDGFR $\beta$, Masitinib, was evaluated at $5 \mu \mathrm{M}$ and $10 \mu \mathrm{M}$ in MCF-7 and MDA-MB-231 cells and was found to significantly inhibit migration in both MCF-7 and MDAMB-231 cells at both $5 \mu \mathrm{M}$ and $10 \mu \mathrm{M}$ (Figure 4) but did not significantly impact proliferation or apoptosis in either cell line at either concentration (data not shown). Masitinib was not evaluated in the murine mammary tumor cell lines.

\section{Discussion}

Our previous study showed that murine claudin-low mammary tumor cells expressed elevated levels of PDGFR $\alpha$ and PDGFR $\beta$ compared to murine luminal mammary tumor cells. In addition, knockdown of PDGFR $\alpha$ or PDGFR $\beta$ significantly reduced migration but not proliferation of the claudin-low mammary tumor cells [25]. Although targeting PDGFRs with RNAi is a useful scientific tool, this approach is unlikely to be clinically viable. Therefore we examined the efficacy of several PDGFR small molecule inhibitors in both our murine mammary tumor cell lines and in human breast cancer cell lines. The cell lines were chosen such that there would be one murine luminal-like (RJ345) and one human luminal cell line (MCF-7) as well as one murine (RJ348) and one human (MDA-MB-231) claudin-low cell line. Since a purely selective PDGFR inhibitor does not 


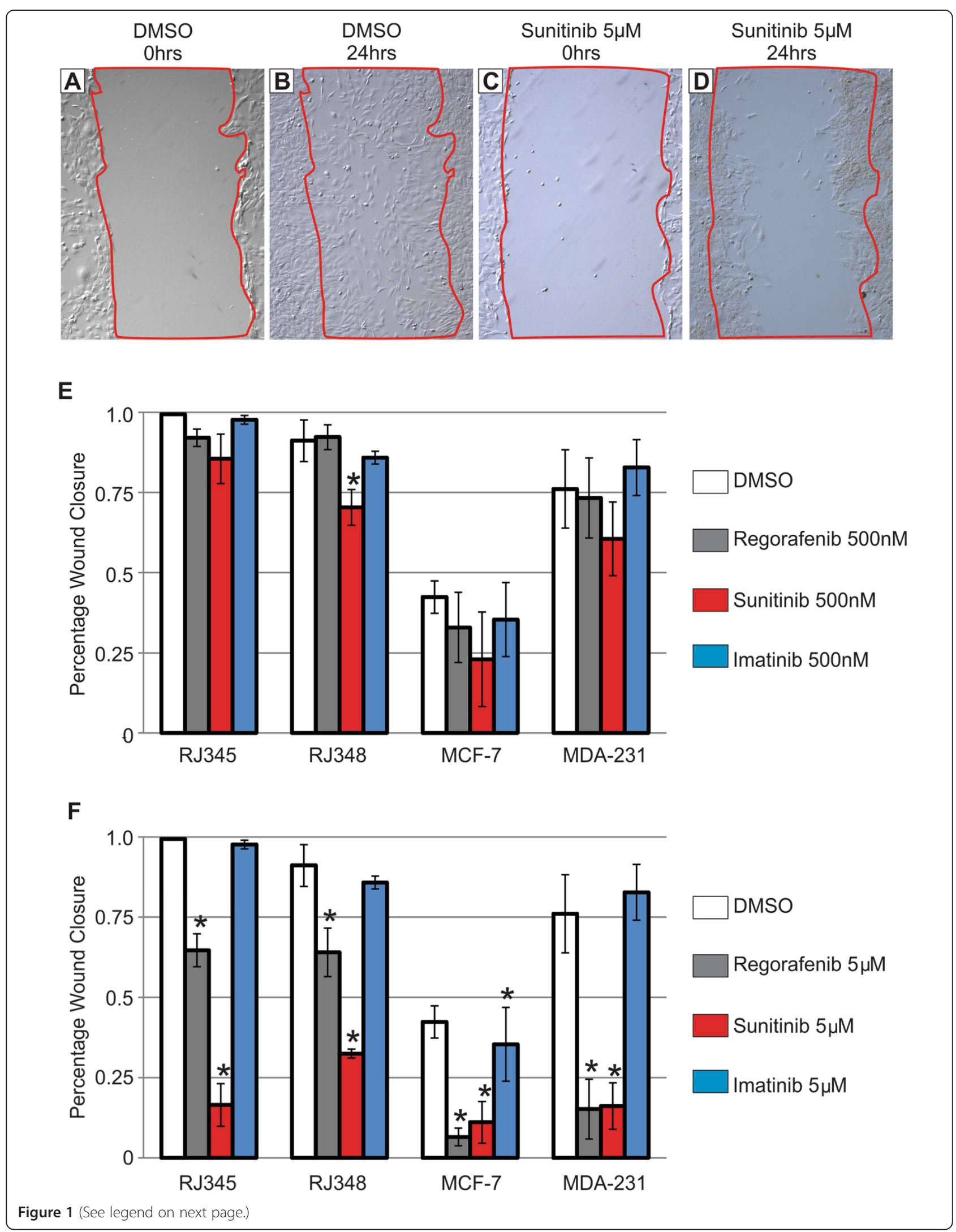


(See figure on previous page.)

Figure 1 Sunitinib and Regorafenib inhibit mammary tumor cell migration. A scratch wound assay was performed on RJ345, RJ348, MCF-7 and MDA-MB-231 cells treated with $500 \mathrm{nM}$ or $5 \mu \mathrm{M}$ of Regorafenib, Sunitinib or Imatinib. (A-D) shows representative scratch wounds from RJ348 cells at time $0(\mathbf{A}, \mathbf{C})$ and 24 hrs $(\mathbf{B}, \mathbf{D})$ after the initiation of the scratch when the cells were treated with the vehicle control, DMSO $(\mathbf{A}, \mathbf{B})$, or $5 \mu M$ of Sunitinib $(\mathbf{C}, \mathbf{D})$. The red line indicates the initial scratch wound. The percentage of the wound closed was quantified from a minimum of 3 independent replicates and is expressed as mean \pm SEM when treated with (E) $500 \mathrm{nM}$ or (F) $5 \mu \mathrm{M}$ of Regorafenib, Sunitinib or Imatinib. Wounds were created and inhibitors were added immediately. Wounds were evaluated at 24 hrs after inhibitor administration for the RJ348 cells and 48 hrs for RJ345, MCF-7 and MDA-MB-231 cells. *Indicates values that were significantly different $(p<0.05)$ from the DMSO control.

currently exist, we selected 3 inhibitors that target PDGFR and are currently used clinically. These inhibitors were Regorafenib (Bay 73-4506), Imatinib mesylate (Gleevec) and Sunitinib malate (Sutent). In addition, Masitinib, which is not clinically used for human cancers but is used for canine mast cell tumors [24] was evaluated in the human breast cancer cell lines. Masitinib was included in the study as it inhibits PDGFR $\alpha$ and PDGFR $\beta$ (similar to Imatinib) while Regorafenib and Sunitinib only inhibit PDGFR $\beta$.

There were a number of surprising findings in this study. The first surprising finding was that Regorafenib and Sunitinib were equally capable of suppressing mammary tumor cell migration and proliferation in both luminal-like and claudin-low cell types. Based on western blots from our previous study [25] we anticipated either (i) the claudin-low tumor cells would be more sensitive to PDGFR inhibition as these cells express higher levels of PDGFR and thus were more dependent on PDGFR signaling for migration and proliferation or (ii) the higher levels of PDFGR found in the claudin-low tumor cells would render these cells more resistant to PDGFR inhibition as higher concentrations of Sunitinib or Regorafenib would be required to competitively block PDGFR signaling. The percentage of migration inhibited was similar in the luminal-like cell lines compared to their claudin-low counterparts indicating that PDFGR expression did not predict sensitivity to PDGFR inhibition. However, it does appear that both luminal-like and claudin low breast cancer cells rely on PDGFR signaling for migration and that PDGFR inhibitors can effectively suppress migration even in cells that express high levels of PDGFRs.

The second surprising finding was that Sunitinib inhibited proliferation of the claudin-low cell lines. At least for the RJ348 cells, our previous study showed that knockdown of PDGFR either had no effect on proliferation or induced a slight increase in proliferation. In the current study Sunitinib inhibited proliferation of all four cell lines. This effect is likely results from inhibition of kinases other than PDGFR $\beta$.

The third surprising finding was that Imatinib was less effective at inhibiting migration than either Sunitinib or Regorafenib. Our previous study showed that concomitant knockdown of both PDGFR $\alpha$ and PDGFR $\beta$ was the most effective strategy for inhibiting RJ348 migration and knockdown of PDGFR $\alpha$ was more effective at suppressing

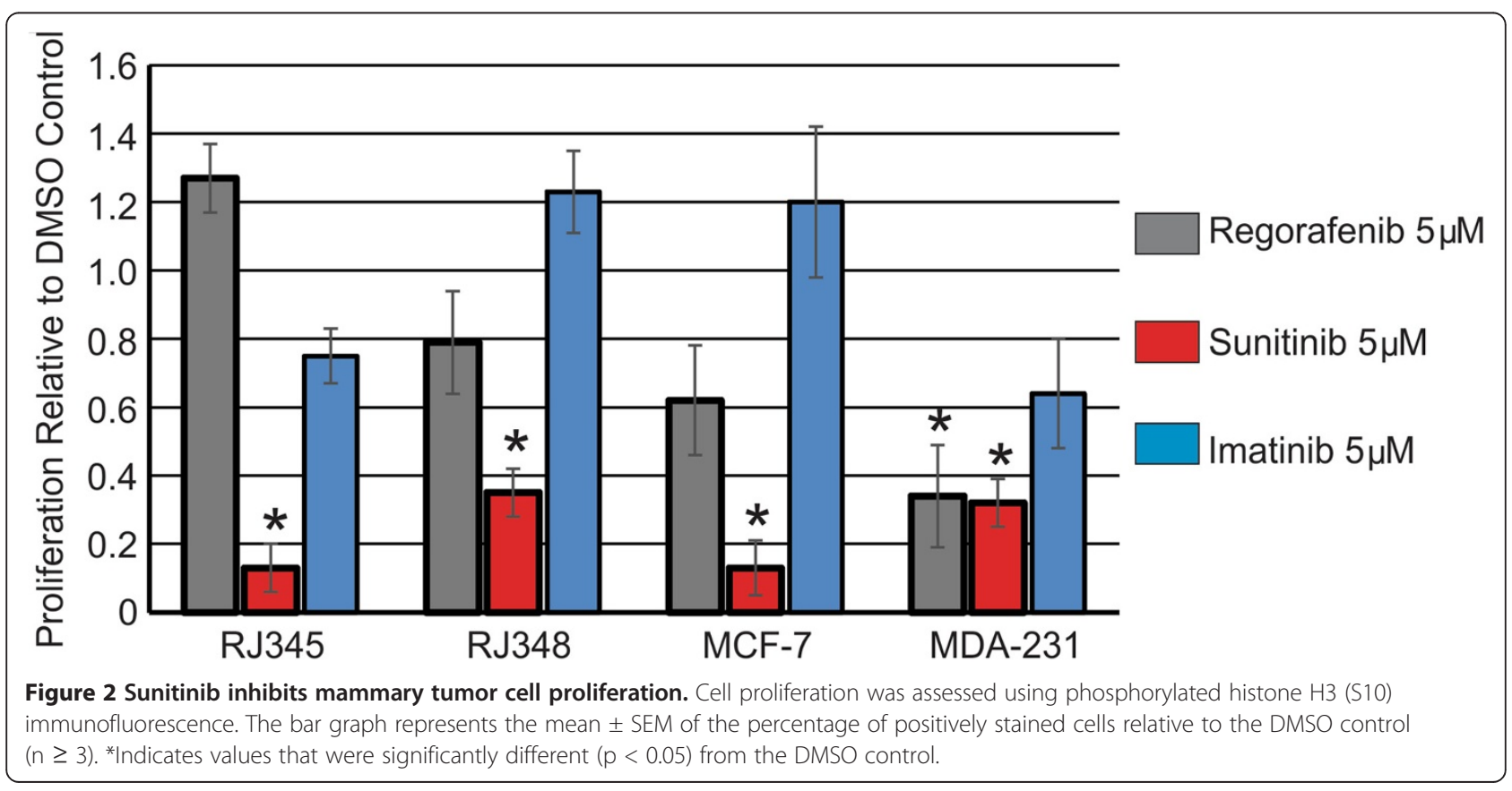




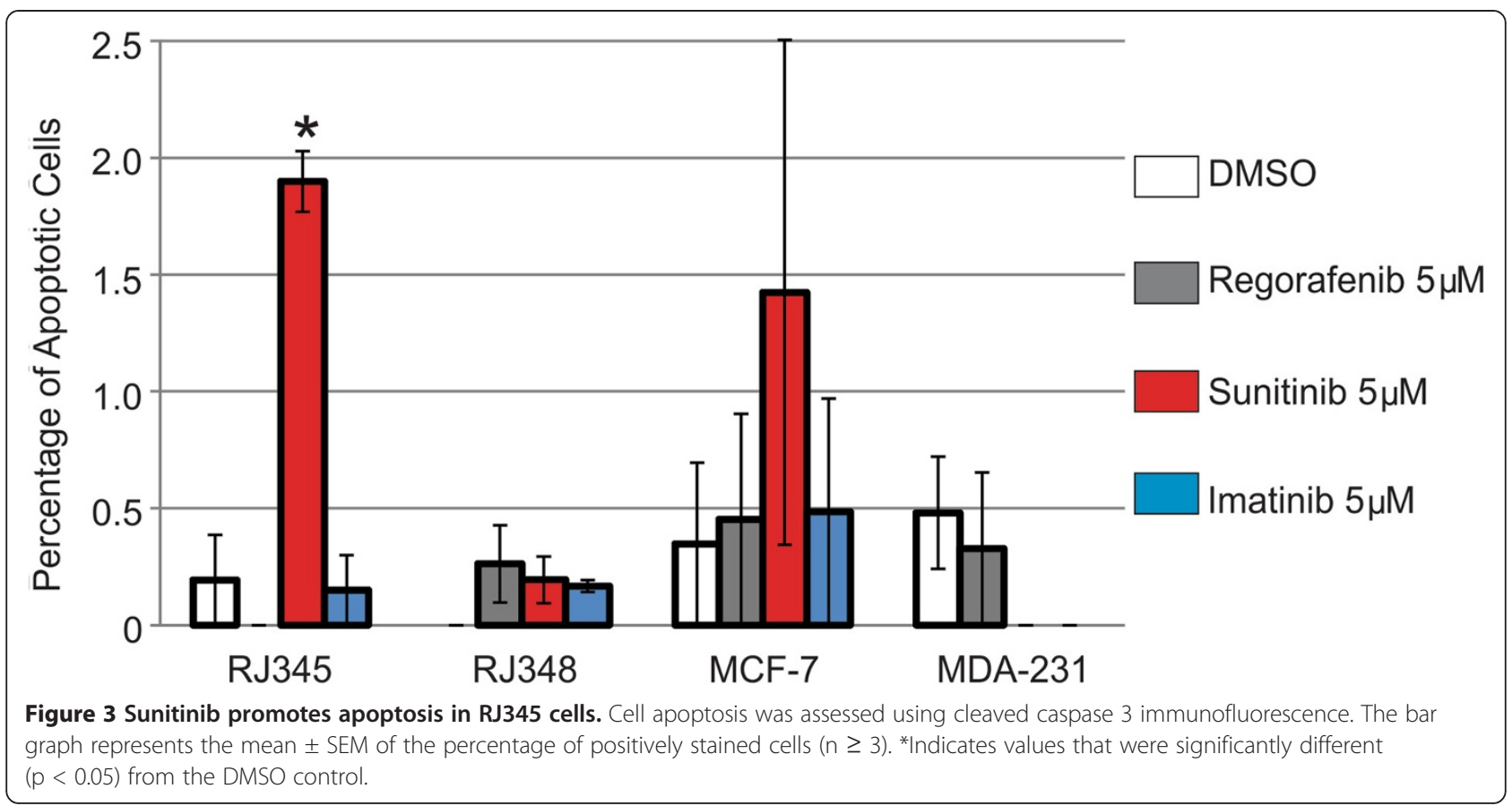

migration than PDGFR $\beta$ knockdown [25]. Since Imatinib targets both PDGFR $\alpha$ and PDGFR $\beta$ while Sunitinib and Regorafenib only target PGDFR $\beta$, we anticipated that Imatinib would be the most effective inhibitor at suppressing tumor cell migration. The lack of effect of Imatinib could be due to the higher $\mathrm{IC}_{50}$ for PDGFR inhibition $(100 \mathrm{nM})$ compared to Sunitinib (PDGFR $\beta \mathrm{IC}_{50}$ of $2 \mathrm{nM}$ ) and Regoragenib (PDGFR $\beta \mathrm{IC}_{50}$ of $22 \mathrm{nM}$ ). It is also possible that a kinase targeted by both Sunitinib and Regorafenib, but not Imatinib, is critical for migration and proliferation in the tumor cells tested. However, the fact that Masitinib, which inhibits both PDGFR $\alpha$ and PDGFR $\beta$ as well as c-kit (similar to Imatinib), significantly inhibited migration of both human breast cancer cell lines, but had no effect on proliferation or apoptosis argues against the $\mathrm{IC}_{50}$ or other kinase targets limiting Imatinib's efficacy. Masitinib's $\mathrm{IC}_{50}$ for PDGFR $\alpha$ and PDGFR $\beta$ is reported to be higher than Imatinib's and the kinases inhibited by Masitinib are also inhibited by Imatinib. Therefore, it appears that inhibition of PDGFR $\beta$ can suppress breast cancer cell migration but

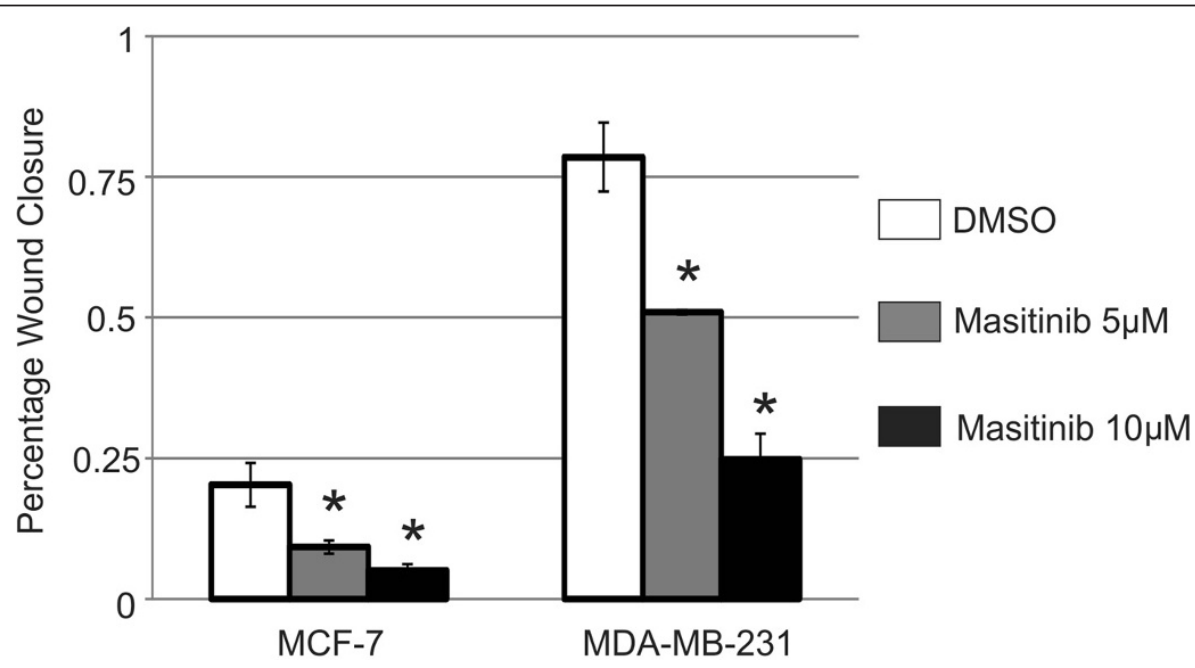

Figure 4 Masitinib inhibits migration of MCF-7 and MDA-MB-231 cells. The bar graph represents the percentage of the wound closed from 3 independent scratch wound assays and is expressed as mean \pm SEM when treated with (grey bar) $5 \mu \mathrm{M}$ or (black bar) $10 \mu \mathrm{M}$ of Masitinib. Masitinib was added to the cells immediately after the creation of the wound and wounds were evaluated at 48 hrs after inhibitor administration. *Indicates values that were significantly different $(p<0.05)$ from the DMSO control. 
does not regulate breast cancer cell proliferation. This would be consistent with our observations using PDGFR RNAi in RJ345 and RJ348 cells in that inhibition of PDGFRs can suppress migration but not proliferation [25]. The ability of Sunitinib and Regorafenib to inhibit breast cancer cell proliferation presumably results from inhibition of a kinase other than PDGFR $\beta$. The only kinase reported to be targeted by both Sunitinib and Regorafenib (that is not targeted by Masitinib) is VEGFR2 and thus this receptor deserves further investigation as an anti-proliferative agent in the treatment of breast cancer.

A review of the literature revealed that Regorafenib has not been tested on MCF-7 or MDA-MB-231 cells in vitro. One manuscript did evaluated the effects of Regorafenib on MDA-MB-231 cells in vivo and found that Regorafenib at $3 \mathrm{mg} / \mathrm{kg}$ and higher significantly inhibited MDA-MB-231 xenograft growth [21]. For Sunitinib, one manuscript examined MCF-7 and MDAMB-231 proliferation in vitro. This study showed that $5 \mathrm{uM}$ of Sunitinib significantly inhibited proliferation of both MCF-7 and MDA-MB-231 cells as assessed using a $\mathrm{H}^{3}$-thymidine assay. Migration was not evaluated [31]. Three studies examined the effects of Imatinib on MCF-7 and MDA-MB-231 cells in vitro. One study showed that the $\mathrm{IC}_{50}$ of Imatinib in both MCF-7 and MDA-MB-231 cells was approximately $7 \mathrm{uM}$ [32]. At $5 \mu \mathrm{M}$, Imatinib reduced MDA-MB-231 proliferation to approximately $75 \%$ of control and MCF-7 proliferation to approximately $85 \%$ of control [32]. In the second study it was found that imatinib at concentrations of $3 \mathrm{uM}$ and higher could inhibit proliferation of both MCF-7 and MDA-MB-231, however, these studies were performed in serum-free conditions [33]. The final study showed that Imatinib could inhibit MCF-7 but not MDA-MB-231 cell migration at $48 \mathrm{hrs}$ after administration of $6 \mathrm{uM}$ of Imatinib when the cells were cultured in 1\% serum [34]. Therefore, our findings on Regorafenib, Sunitinib and Imatinib are consistent with the limited number of breast cancer studies using these agents. No study has evaluated Masitinib treatment on MCF-7 or MDA-MB-231 cells. Therefore, this is the first study to demonstrate that Masitinib can inhibit migration of luminal and claudin-low human breast cancer cells but has no significant impact on proliferation or apoptosis.

Pharmacokinetic studies in mice and rats have shown maximal plasma concentrations of Sunitinib that can be achieved are in the range of 3-3.5 $\mu \mathrm{M}$ [35]. In humans, administration of more than $50 \mathrm{mg}$ of Sunitinib daily is associated with significant toxicity and at $50 \mathrm{mg} /$ day, plasma levels of Sunitinib range from $50-90 \mathrm{ng} / \mathrm{ml}(\sim 0.1$ $\mu \mathrm{M}-0.17 \mu \mathrm{M})$ [36]. However, a study by Gotink et al. [37] has shown that intratumoral concentrations of Sunitinib are more than 10 -fold higher than plasma samples. In mice administered Sunitinib at $40 \mathrm{mg} / \mathrm{kg} /$ day, plasma concentrations were approximately $1 \mu \mathrm{M}$ while tumor concentrations were approximately $11 \mu \mathrm{M}$. Similarly in humans administered 37.5-50 mg of Sunitinib per day, plasma concentrations were approximately $0.3 \mu \mathrm{M}$ while tumor concentrations were approximately $9.5 \mu \mathrm{M}$. For Regorafenib and Imatinib, plasma concentrations of $2522 \mathrm{ng} / \mathrm{ml}(5.2 \mu \mathrm{M})$ and $3000 \mathrm{ng} / \mathrm{ml}(5.1 \mu \mathrm{M})$ respectively, have been reported [38,39]. Plasma concentrations for Masitninb in humans has not been reported but concentrations of $1886 \mathrm{ng} / \mathrm{ml}(3.9 \mu \mathrm{M})$ have been reported in cats [40]. Therefore, the concentrations used in this study are within the range of those clinically achievable.

Although clinical trials using Sunitinib in the treatment of breast cancer have been disappointing thus far [41-43] a recent study from the Weinberg lab reinforces the importance of PDGFR signaling in breast cancer. These investigators found that that EMT and the enrichment of breast cancer stem cells was associated with a switch from EGFR signaling to PDGFR signaling [44]. In addition this study showed that PDGFR expression was elevated in mammary tumor cells with stem cell properties and PDGFR inhibitors could selectively target breast cancer cells with stem cell properties [44]. Therefore, additional research is required to identify specific PDGFR inhibitors and how best to utilize these agents for targeting different breast cancer subtypes or specific cell types (ie stem cells) in breast cancers.

\section{Competing interests}

The authors declare that they have no competing interests.

\section{Authors' contributions}

LS performed some of the proliferation and migration assays using Sunitinib, Regorafenib and Imatinib and contributed to the drafting of the manuscript. JP performed the experiments with Masitinib. RAM ran the project, performed some of the proliferation, migration and apoptosis assays with Sunitinib, Regorafenib and Imatinib and wrote the manuscript. All authors read and approved the final manuscript.

\section{Acknowledgements}

This work was supported through a grant from the Canadian Institutes of Health Research to RAM.

Received: 26 March 2014 Accepted: 29 August 2014

Published: 5 September 2014

\section{References}

1. Raines EW, Ross R: Platelet-derived growth factor. I. High yield purification and evidence for multiple forms. J Biol Chem 1982, 257(9):5154-5160.

2. Heldin $\mathrm{CH}$, Westermark B, Wasteson A: Platelet-derived growth factor: purification and partial characterization. Proc Natl Acad Sci U S A 1979, 76(8):3722-3726.

3. Deuel TF, Huang JS, Proffitt RT, Baenziger JU, Chang D, Kennedy BB: Human platelet-derived growth factor. Purification and resolution into two active protein fractions. J Biol Chem 1981, 256(17):8896-8899.

4. Antoniades HN, Scher CD, Stiles CD: Purification of human platelet-derived growth factor. Proc Natl Acad Sci U S A 1979, 76(4):1809-1813.

5. Heldin $\mathrm{CH}$ : Autocrine PDGF stimulation in malignancies. Ups J Med Sci 2012, 117(2):83-91. 
6. Zhang P, Gao WY, Turner S, Ducatman BS: Gleevec (STI-571) inhibits lung cancer cell growth (A549) and potentiates the cisplatin effect in vitro. Mol Cancer 2003, 2:1

7. Jones AV, Cross NC: Oncogenic derivatives of platelet-derived growth factor receptors. Cell Mol Life Sci 2004, 61(23):2912-2923.

8. Hayden K, Tetlow L, Byrne G, Bundred N: Radioimmunoassay for the measurement of thrombospondin in plasma and breast cyst fluid: validation and clinical application. Ann Clin Biochem 2000, 37(Pt 3):319-325

9. Faroogi AA, Waseem S, Riaz AM, Dilawar BA, Mukhtar S, Minhaj S, Waseem MS, Daniel S, Malik BA, Nawaz A, Bhatti S: PDGF: the nuts and bolts of signalling toolbox. Tumour Biol 2011, 32(6):1057-1070.

10. Seymour L, Dajee D, Bezwoda WR: Tissue platelet derived-growth factor (PDGF) predicts for shortened survival and treatment failure in advanced breast cancer. Breast Cancer Res Treat 1993, 26(3):247-252.

11. Kawai T, Hiroi S, Torikata C: Expression in lung carcinomas of platelet-derived growth factor and its receptors. Lab Invest 1997, 77(5):431-436.

12. Weigel MT, Ghazoui Z, Dunbier A, Pancholi S, Dowsett M, Martin LA: Preclinical and clinical studies of estrogen deprivation support the PDGF/Abl pathway as a novel therapeutic target for overcoming endocrine resistance in breast cancer. Breast Cancer Res 2012 14(3):R78.

13. Weigel MT, Banerjee S, Arnedos M, Salter J, A'Hern R, Dowsett M, Martin LA: Enhanced expression of the PDGFR/Abl signaling pathway in aromatase inhibitor-resistant breast cancer. Ann Oncol 2013, 24(1):126-133.

14. Thiery JP, Acloque H, Huang RY, Nieto MA: Epithelial-mesenchymal transitions in development and disease. Cell 2009, 139(5):871-890.

15. Dave B, Mittal V, Tan NM, Chang JC: Epithelial-mesenchymal transition, cancer stem cells and treatment resistance. Breast Cancer Res 2012, 14 (1):202.

16. Foroni C, Broggini M, Generali D, Damia G: Epithelial-mesenchymal transition and breast cancer: role, molecular mechanisms and clinical impact. Cancer Treat Rev 2012, 38(6):689-697.

17. Drasin DJ, Robin TP, Ford HL: Breast cancer epithelial-to-mesenchymal transition: examining the functional consequences of plasticity. Breast Cancer Res 2011, 13(6):226.

18. Sun L, Liang C, Shirazian S, Zhou Y, Miller T, Cui J, Fukuda JY, Chu JY, Nematalla A, Wang $X$, Chen H, Sistla A, Luu TC, Tang F, Wei J, Tang C: Discovery of 5-[5-fluoro-2-oxo-1,2- dihydroindol-(3Z)-ylidenemethyl]-2, 4- dimethyl-1H-pyrrole-3-carboxylic acid (2-diethylaminoethyl)amide, a novel tyrosine kinase inhibitor targeting vascular endothelial and platelet-derived growth factor receptor tyrosine kinase. J Med Chem 2003, 46(7):1116-1119.

19. O'Farrell AM, Abrams TJ, Yuen HA, Ngai TJ, Louie SG, Yee KW, Wong LM Hong W, Lee LB, Town A, Smolich BD, Manning WC, Murray L, Heinrich MC, Cherrington JM: SU11248 is a novel FLT3 tyrosine kinase inhibitor with potent activity in vitro and in vivo. Blood 2003, 101(9):3597-3605.

20. Mendel DB, Laird AD, Xin X, Louie SG, Christensen JG, Li G, Schreck RE, Abrams TJ, Ngai TJ, Lee LB, Murray L, Carver J, Chan E, Moss KG, Haznedar JO, Sukbuntherng J, Blake RA, Sun L, Tang C, Miller T, Shirazian S, McMahon G, Cherrington JM: In vivo antitumor activity of SU11248, a novel tyrosine kinase inhibitor targeting vascular endothelial growth factor and platelet-derived growth factor receptors: determination of a pharmacokinetic/pharmacodynamic relationship. Clin Cancer Res 2003, 9(1):327-337.

21. Wilhelm SM, Dumas J, Adnane L, Lynch M, Carter CA, Schutz G, Thierauch KH, Zopf D: Regorafenib (BAY 73-4506): a new oral multikinase inhibitor of angiogenic, stromal and oncogenic receptor tyrosine kinases with potent preclinical antitumor activity. Int J Cancer 2011, 129(1):245-255.

22. Heng DY, Kollmannsberger $C_{1}$ Chi KN: Targeted therapy for metastatic renal cell carcinoma: current treatment and future directions. Ther $A d v$ Med Oncol 2010, 2(1):39-49.

23. Dubreuil P, Letard S, Ciufolini M, Gros L, Humbert M, Casteran N, Borge L, Hajem B, Lermet A, Sippl W, Voisset E, Arock M, Auclair C, Leventhal PS, Mansfield CD, Moussy A, Hermine O: Masitinib (AB1010), a potent and selective tyrosine kinase inhibitor targeting KIT. PLoS One 2009, 4(9):e7258.

24. Hahn KA, Ogilvie G, Rusk T, Devauchelle P, Leblanc A, Legendre A, Powers B, Leventhal PS, Kinet JP, Palmerini F, Dubreuil P, Moussy A, Hermine O: Masitinib is safe and effective for the treatment of canine mast cell tumors. $J$ Vet Intern Med 2008, 22(6):1301-1309.
25. Campbell $\mathrm{Cl}$, Moorehead RA: Mammary tumors that become independent of the type I insulin-like growth factor receptor express elevated levels of platelet-derived growth factor receptors. BMC Cancer 2011, 11:480.

26. Campbell Cl, Thompson DE, Siwicky MD, Moorehead RA: Murine mammary tumor cells with a claudin-low genotype. Cancer Cell Int 2011, 11:28.

27. Franks SE, Campbell Cl, Barnett EF, Siwicky MD, Livingstone J, Cory S, Moorehead RA: Transgenic IGF-IR overexpression induces mammary tumors with basal-like characteristics while IGF-IR independent mammary tumors express a claudin-low gene signature. Oncogene 2012, 31(27):3298-3309.

28. Prat A, Parker JS, Karginova O, Fan C, Livasy C, Herschkowitz Jl, He X, Perou CM: Phenotypic and molecular characterization of the claudin-low intrinsic subtype of breast cancer. Breast Cancer Res 2010, 12(5):R68.

29. Hennessy BT, Gonzalez-Angulo AM, Stemke-Hale K, Gilcrease MZ, Krishnamurthy S, Lee JS, Fridlyand J, Sahin A, Agarwal R, Joy C, Liu W, Stivers D, Baggerly K, Carey M, Lluch A, Monteagudo C, He X, Weigman V, Fan C, Palazzo J, Hortobagyi GN, Nolden LK, Wang NJ, Valero V, Gray JW, Perou CM, Mills GB: Characterization of a naturally occurring breast cancer subset enriched in epithelial-to-mesenchymal transition and stem cell characteristics. Cancer Res 2009, 69(10):4116-4124.

30. Jones RA, Campbell Cl, Petrik JJ, Moorehead RA: Characterization of a novel primary mammary tumor cell line reveals that cyclin D1 is regulated by the type I insulin-like growth factor receptor. Mol Cancer Res 2008, 6(5):819-828.

31. Young E, Miele L, Tucker KB, Huang M, Wells J, Gu JW: SU11248, a selective tyrosine kinases inhibitor suppresses breast tumor angiogenesis and growth via targeting both tumor vasculature and breast cancer cells. Cancer Biol Ther 2010, 10(7):703-711.

32. Weigel MT, Meinhold-Heerlein I, Bauerschlag DO, Schem C, Bauer M, Jonat W, Maass N, Mundhenke C: Combination of imatinib and vinorelbine enhances cell growth inhibition in breast cancer cells via PDGFR beta signalling. Cancer Lett 2009, 273(1):70-79.

33. Malavaki CJ, Roussidis AE, Gialeli C, Kletsas D, Tsegenidis T, Theocharis AD, Tzanakakis GN, Karamanos NK: Imatinib as a key inhibitor of the platelet-derived growth factor receptor mediated expression of cell surface heparan sulfate proteoglycans and functional properties of breast cancer cells. The FEBS journal 2013, 280(10):2477-2489.

34. Weigel MT, Dahmke L, Schem C, Bauerschlag DO, Weber K, Niehoff P, Bauer M, Strauss A, Jonat W, Maass N, Mundhenke C: In vitro effects of imatinib mesylate on radiosensitivity and chemosensitivity of breast cancer cells. BMC Cancer 2010, 10:412.

35. Haznedar JO, Patyna S, Bello CL, Peng GW, Speed W, Yu X, Zhang Q, Sukbuntherng J, Sweeny DJ, Antonian L, Wu EY: Single- and multiple-dose disposition kinetics of sunitinib malate, a multitargeted receptor tyrosine kinase inhibitor: comparative plasma kinetics in non-clinical species. Cancer Chemother Pharmacol 2009, 64(4):691-706.

36. Britten CD, Kabbinavar F, Hecht JR, Bello CL, Li J, Baum C, Slamon D: A phase I and pharmacokinetic study of sunitinib administered daily for 2 weeks, followed by a 1-week off period. Cancer Chemother Pharmacol 2008, 61(3):515-524.

37. Gotink KJ, Broxterman HJ, Labots M, de Haas RR, Dekker H, Honeywell RJ, Rudek MA, Beerepoot LV, Musters RJ, Jansen G, Griffioen AW, Assaraf YG, Pili R, Peters GJ, Verheul HM: Lysosomal sequestration of sunitinib: a novel mechanism of drug resistance. Clin Cancer Res 2011, 17(23):7337-7346.

38. Sunakawa Y, Furuse J, Okusaka T, Ikeda M, Nagashima F, Ueno H, Mitsunaga S, Hashizume K, Ito Y, Sasaki Y: Regorafenib in Japanese patients with solid tumors: phase I study of safety, efficacy, and pharmacokinetics. Invest New Drugs 2014, 32(1):104-112.

39. Golabchifar AA, Rezaee S, Ghavamzadeh A, Alimoghaddam K, Dinan NM, Rouini MR: Population pharmacokinetics of imatinib in Iranian patients with chronic-phase chronic myeloid leukemia. Cancer Chemother Pharmacol 2014, 74(1):85-93.

40. Bellamy F, Bader T, Moussy A, Hermine O: Pharmacokinetics of masitinib in cats. Vet Res Commun 2009, 33(8):831-837.

41. Curigliano G, Pivot X, Cortes J, Elias A, Cesari R, Khosravan R, Collier M, Huang X, Cataruozolo PE, Kern KA, Goldhirsch A: Randomized phase II study of sunitinib versus standard of care for patients with previously treated advanced triple-negative breast cancer. Breast 2013, 22(5):650-656.

42. Crown JP, Dieras V, Staroslawska E, Yardley DA, Bachelot T, Davidson N, Wildiers H, Fasching PA, Capitain O, Ramos M, Greil R, Cognetti F, Fountzilas G, Blasinska-Morawiec M, Liedtke C, Kreienberg R, Miller WH Jr, Tassell V, Huang X, 
Paolini J, Kern KA, Romieu G: Phase III trial of sunitinib in combination with capecitabine versus capecitabine monotherapy for the treatment of patients with pretreated metastatic breast cancer. J Clin Oncol 2013, 31(23):2870-2878

43. Bergh J, Bondarenko IM, Lichinitser MR, Liljegren A, Greil R, Voytko NL, Makhson AN, Cortes J, Lortholary A, Bischoff J, Chan A, Delaloge S, Huang X, Kern KA, Giorgetti $C$ : First-line treatment of advanced breast cancer with sunitinib in combination with docetaxel versus docetaxel alone: results of a prospective, randomized phase III study. J Clin Oncol 2012, 30(9):921-929.

44. Tam WL, Lu H, Buikhuisen J, Soh BS, Lim E, Reinhardt F, Wu ZJ, Krall JA, Bierie B, Guo W, Chen X, Liu XS, Brown M, Lim B, Weinberg RA: Protein kinase $C$ alpha is a central signaling node and therapeutic target for breast cancer stem cells. Cancer Cell 2013, 24(3):347-364.

doi:10.1186/s12935-014-0089-5

Cite this article as: Stalker et al.: Inhibition of proliferation and migration of luminal and claudin-low breast cancer cells by PDGFR inhibitors.

Cancer Cell International 2014 14:89.

\section{Submit your next manuscript to BioMed Central and take full advantage of:}

- Convenient online submission

- Thorough peer review

- No space constraints or color figure charges

- Immediate publication on acceptance

- Inclusion in PubMed, CAS, Scopus and Google Scholar

- Research which is freely available for redistribution 